\title{
REUTULISASI SEDIMEN HASIL PEKERJAAN PENGERUKAN SEBAGAI MATERIAL BARU DALAM PEKERJAAN PEMBANGUNAN JALAN
}

\author{
Ernesto Silitonga ${ }^{1}$ \\ ${ }^{1}$ Dosen Pengajar Jurusan Pendidikan Teknik Bangunan, Fakultas Teknik UNIMED \\ (ernestosilitonga@yahoo.fr)
}

\begin{abstract}
ABSTRAK
Aplikasi pendayagunaan ulang dari limbah hasil pekerjaan pengerukan pelabuhan di Indonesia semakin dibutuhkan. Oleh sebab itu seluruh informasi yang menyangkut limbah hasil pekerjaan pengerukan ini sangat diperlukan baik informasi teknologi, secara ekonomi, hal ini sangat diperlukan dalam tujuan agar pihak berwenang dapat memutuskan regulasi terbaik yang menyangkut hal ini dikarenakan lokasi untuk menimbun limbah hasil pekerjaan pengerukan ini harus segera ditentukan. Salah satu aplikasi penggunaan ulang limbah hasil pekerjaan pengerukan ini adalah sebagai material dalam pekerjaan fondasi jalan raya. Metode pekerjaan dan penggunaan dari limbah ini dengan menggunakan agen pengikat hidrolik akan diperlihatkan dalam tulisan ini. Tujuan utama dari tulisan ini adalah untuk memperlihatkan efek yang ditimbulkan dari menggunakan agen pengikat hidrolik pada limbah, dalam kegunaannya di pekerjaan pembangunan jalan. Penggunaan semen sebagai agen pengikat ddilihat dari sisi teknik, ekonomi dan ekologi. Tahap pertama adalah mengidentifikasi prilaku mekanik dari sedimen limbah hasil pekerjaan pengerukan. Tahap ini terdiri dari mengidentifikasi karakteristik original dari sedimen itu sendiri dan prilaku mekanik setelah dicampur dengan agen pengikat (dengan berbagai persentase). Hasil percobaan ini kemudian dianalisa dan disimpulajn bahwa penambahan agen pengikat meningkatkan kemampuan mekanik dari campuran limbah tersebut.
\end{abstract}

Kata Kunci : Pengerukan Sedimen, Pengikat Hidrolik, Kekuatan Tarik.

\begin{abstract}
Efficient and environmentally reutilization of dredged waste material in Indonesia calls for a multi disciplinary effort. That is why, the scientific, technological and economic information required to make an optimal choice among dredged waste because material disposal sites is now urgently needed in Indonesia. The reuse of dredged sediment as a new material for the construction of foundation and base layers for roads is one of the solution. An effective method for reusing dredged waste materials as a new material in road construction is illustrated in this paper using hydraulics binders (Cement and Lime). The main goal of this study is to describe the behavioural aspect of dredged sediment stabilized with hydraulic binders as a binder for a use in road pavement work. The addition of cement is realized due to its engineering, economic and ecological benefits. The first stepidentify the mechanicalcharacteristics of the dredged sediments. Thisstage consists of identifying mechanicalbehaviour of dredged sediment with addition of different percentage of hydraulics binders, the mechanical identification of dredged sediments with variouspercentage of binders (with or without hydraulics binders) were performed, compared and analysed. The results show that the addition of hydraulics binders in mixture improves mechanical characteristics
\end{abstract}

Keywords: Polluted dredged sediments, hydraulic binders, unconfined compressive strength, Tensile strength. 


\section{Pendahuluan}

Seperti yang telah dikemukakan sebelumnya, bahwa dalam merencanakan pembangunan dan pengembangan Pelabuhan, masalah sedimentasi atau pendangkalan harus diminimalisasi terutama pada kolam Pelabuhan dan alur pelayaran guna mengamankan dan melancarkan arus pelayaran. Masalah pendangkalan ini akan semakin besar dan kompleks jika Pelabuhan tersebut terletak di muara sungai (estuary). Seperti kita ketahui bahwa secara geografis, Pelabuhan Belawan berada pada dua muara sungai yaitu Sungai Belawan dan Sungai Deli, dapat disimpulkan bahwa proses sedimentasi tidak hanya dipengaruhi oleh pasang surut dan arus laut saja akan tapi lebih dipengaruhi oleh debit kedua air sungai tersebut. Sehubungan dengan hal tersebut, untuk mengurangi pendangkalan yang diakibatkan oleh sedimentasi adalah dengan cara melakukan pengerukan alur pelayaran dan kolam Pelabuhan. Setelah pengerukan sedimen dilakukan, sedimen (terpolusi atau tidak) langsung disebarkan/ buang ke tengah laut. Proses pembuangan sedimen hasil pengerukan ini masih dilakukan dalam setiap perkerjaan pengerukan di wilayah Indonesia. Pekerjaan pembuangan sedimen ke tengah laut ini sangat berdampak negatif terhadap lingkungan disekitar daerah tersebut.

Dalam penelitian tahap kedua ini proses penggunaan binder (bahan pengikat) merupakan langkah yang akan diteliti selanjutnya. Penggunaan binder ini diharapakn memberikan hasil yang lebih memuaskan disbanding binder sebelumnya (semen dan kapur). Binder yang akan digunakan dalam penelitian ini adalah binder jenis abu terbang. Binder ini merupakan material yang memiliki reaksi pozzolanic. Melalui binder pzzolanic ini diharapkan adanya peningkatan performa dari sampel sehingga sesuai dengan syarat-syarat yang diperlukan dalam pekerjaan pembangunan jalan. Tujuan dari penelitian ini adalah, dengan beragam masukan dan referensi informasi (dari pelabuhan yang berbeda) yang diperoleh, penelitian selanjutnya dapat memproduksi pengklasifikasian tingkat polusi dari sedimen hasil pengerukan, sehingga pelaksana pekerjaan pengerukan ini nantinya mempunyai referensi untuk menindak lanjuti proses akhir pekerjaan pengerukan ini. Sehingga penyebaran sedimen yang dikategorikan terpolusi tidak lagi dibuang ke laut, melainkan diproses ulang untuk digunakan sbagai material yang aman terhadap lingkungan. Sasaran jangka panjang berikutnya adalah agar nantinya para pelaksana dalam bidang pengerukan ini, mempunyai alternatif pengaplikasian dan pendayagunaan ulang dari material ini, sehingga tidak hanya menjaga lingkungan tetapi juga memberikan keuntungan.

\section{Landasan Teori}

Masalah utama yang ingin disampaikan dalam penelitian ini adalah pekerjaan pembuangan sedimen hasil pekerjaan pengerukan ke tengah laut yang merupakan tindakan yang sangat berdampak negatif terhadap lingkungan disekitar daerah pelabuhan. Dalam rangka memperkuat argumentasi untuk tidak membuang sedimen hasil pengerukan kedalam laut. Penelitan ini memberikan pilihan untuk memperlihatkan bahwa sedimen hasil pekerjaan pengerukan dapat digunakan kembali sebagai material baru.

Penggunaan kembali dari sedimen hasil pekerjaan pengerukan ini sangat diperlukan karena apabila tidak maka jumlah sedimen yang ditimbun setiap tahun akan terus meningkat. Pekerjaan pembuangan sedimen hasil pekerjaan pengerukan ke tengah laut merupakan tindakan yang sangat berdampak negatif terhadap lingkungan disekitar daerah tersebut, oleh karena hal tersebut dalam rangka mencegah pembuangan sedimen hasil pekerjaan pengerukan, maka penimbunan sedimen di tanah merupakan tahap awal dari pekerjaan tersebut. Penelitian yang dilakukan oleh Silitonga (Silitonga E. et al., 2008*1) berusaha untuk menemukan alternatif melalui binder pozzolanic. Penelitian yang dilakukan oleh Silitonga, berusaha melakukan solusi dengan meneliti sedimen hasil pengerukan pelabuhan Cherbourg-Basse Normandie, Prancis Penelitian ini disponsori oleh Pelabuhan Cherbourg-Basse Normandie, Prancis. Penelitian ini direalisasikan dengan menggunakan limbah industri lainnya, yaitu Abu terbang, Penelitian ini menunjukkan hasil 


\section{Reutulisasi Sedimen Hasil Pekerjaan Pengerukan Sebagai Material Baru Dalam Pekerjaan Pembangunan Jalan}

dari test unconfined strength dimana sampel yang menggunakan abu terbang sebagai binder menunjukkan hasil yang sangat memuaskan dimana penambahan nilai daya tekan terus meningkat naik setelah 28 Hasil ini juga menunjukkan bahwa peran dari kapur dalam meningkatkan $\mathrm{pH}$ yang berguna untuk menambah kinerja reaksi pozzolanic dari abu terbang.

Dari foto hasil daya tekan ini dapat kita saksikan bahwa seluruh sampel dengan campuran abu terbang sebagai binder memperlihatkan peningkatan nilai daya tekan sedikit demi sedikit setelah 28 hari. Sementara Sampel yang hanya menggunakan semen sebagai binder menunjukkan peningkatan nilai daya tekan dari awal hingga 60 hari, namun setelah itu peningkatan dari nilai daya tekan tersebut tidak menunjukkan hasil yang signifikan. Penelitian yang dilakukan Silitonga pada tahun 2009 terhadap sedimen Port en Bessin (ErnestoSilitonga E. et al., 2009*1) memperlihatkan hasil penelitian dimana,pengaruh faktor kimia, mineralogi dan ukuran granulometri dari dua jenis abu terbang terhadap perannya dalam proses penstabilisasian sedimen hasil pengerukan dari Pelabuhan Cherbourg-Basse Normandie, Prancis. kadar $\mathrm{SiO}_{2}, \mathrm{Fe}_{2} \mathrm{O}_{3}$ dan $\mathrm{AL}_{2} \mathrm{O}_{3}$ dalam abu terbang sama pentingnya terhadap kadar SO, Total $\mathrm{CaO}$ dan Free $\mathrm{CaO}$ dalam penggunaannya sebagai binder. Akan tetapi dari hasil percobaan ini dapat dipastikan bahwa peranan $\mathrm{SiO}_{2}, \mathrm{Fe}_{2} \mathrm{O}_{3}$ dan $\mathrm{AL}_{2} \mathrm{O}_{3}$ lebih berdampak positif karena abu terbang yang memiliki $\mathrm{SiO}_{2}, \mathrm{Fe}_{2} \mathrm{O}_{3}$ dan $\mathrm{AL}_{2} \mathrm{O}_{3}$ memberikan hasil yang lebih memuaskan dibanding ng lain.

Dari Foto 2 kita dapt memperhatikan bahwa hasil percobaan CBR menunjukkan bahwa nilai IPI dari sampel yang menggunakan abu terbang dan silica fume sebagai binder pengikat memperlihatkan nilai yang sangat tinggi disbanding sampel yang tidak menggunakan binder ataupun sampel yang hanya menggunakan binder hydraulic (semen atau kapur). Hasil percobaan Test ini memperlihatkan bahwa seluruh sampel yang menggunakan abu terbang dan silica fume sebagai binder Pozzolan memperlihatkan nilai IPI yang cukup untuk digunakan sebagai bahan pertimbangan awal dalam pekerjaan pembangunan jalan. Penelitian oleh Ernesto memperlihatkan hasil dari Percobaan Leaching yang memperlihatkan beberapa faktor yang dapat memberi dampak negatif pada sampel dalam memperoleh performa yang diharapkan.

Penelitian yang dilakukan direalisasikan pada tahun 2009 oleh Silitonga. (Silitonga E. et al., 2009*2) yang bertujuan untuk menstabilisasi sedimen hasil pengerukan di pelabuhan Cherbourg-Basse Normandie, Prancis, dengan menggunakan abu terbang sebagai binder Pengikat. Hasil Penelitian ini menunjukkan bahwa persentase kadar polusi dalam sedimen dapat memperlambat atau proses reaksi kimia yang terjadi dalam matrik untuk mendapatkan kekuatan dan kepadatan (solid). Sebaliknya dalam penelitian ini juga dibuktikan bahwa dengan ditambahkannya binder pozzolanic (abu terbang) dalam campuran sampel, selain meningkatkan performa mekanik juga menurunkan kadar polusi pada sedimen

\section{Metodologi Penelitian}

Metode penelitiaan yang diakan digunakan terdiri langkah-langkah dibawah ini :

\subsection{Identifikasi masalah}

Dalam tahap ini, masalah-masalah yang timbul dan terkait mengenai penggunaan ulang sedimen hasil pengerukan dengan menggunakan binder hydraulic yang sebelumnya telah dilakukan dalam penelitian tahap pertama akan dianalisa dan dipelajari,

3.2 Identifikasi karakteristik binder pozzolanic yang akan digunakan.

Dalamtahap identifikasi dari percobaan ini adalah, mengidentifikasi karakteristik/ propoerti mekanik, mineralogi dan kimia, dari binder yang digunakan, dalam hal ini Identifikasi properti fisik / mekanik dari abu terbang ini dilakukan dengan melakukan percobaan- percobaan yang umumnya dilakukan dalam pekerjaan teknik sipil, contohnya: identifikasi distribusi granulometri, percobaan Proctor, California Bearing Ratio (CBR) akan tetapi identifkasi properti kimia dengan Leaching test diperlukan merupakan test yang paling menentukan dalam tahap ini.

\subsection{Penentuan formulasi dari campuran.}

Berdasarkan hasil penelitian dari tahap awal, dapat disimpulkan bahwa penggunaan binder yang memiiliki sifat pozzolanic sangatlah diperlukan. 
Setelah mengidentifikasi kinerja abu terbang kemudian tahap berikutnya direalisasikan dengan mencampur sedimen dengan binder (bahan pengikat) campuran (binder) yang umum digunakan dalam pekerjaan bangunan, seperti semen dan kapur.Abu terbang ini diharapakan dapat mengurangi kadar polusi dari material/ sedimen yang digunakan..Tahap ketiga ini direalisasikan dengan tujuan untuk mengetahui prilaku material/ sedimen terhadap kehadiran binder dalam campuran.

3.4 Analisa hasil

Pada tahap ini, hasil-hasil yang didapat akan dianalisa dan ditentukan apakah formulasi yang telah diterapkan sesuai dengan syarat-syarat yang diperlukan. Sehingga dapat memberikan kesimpulankesimpulan yang dapat digunakan dalam pendayagunaan sedimen hasil pekerjaan pengerukan

\section{Material}

\subsection{Pelabuhan Belawan}

Pelabuhan Belawan terletak 03⒋ $47^{\prime}$ LU dan $98^{\circ} 42^{\prime}$ BT pada semenanjung yang dibatasi Sungai Belawan di bagian Utara dan Sungai Deli di Selatan. Pelabuhan Belawan terletak di Timur Laut Pantai Sumatera $\pm 27 \mathrm{~km}$ dari Medan, ibukota propinsi Sumatera Utara. Pelabuhan Belawan juga terletak pada jalur pelayaran strategis Selat Malaka. Pelabuhan Belawan dimulai dari daerah Tanjung Betung Camar di utara dan memanjang mengikuti garis pantai hingga muara Sungai Belawan dan Sungai Deli. Pelabuhan Belawan memiliki beberapa fasilitas, semuanya terletak di selatan Sungai Belawan.

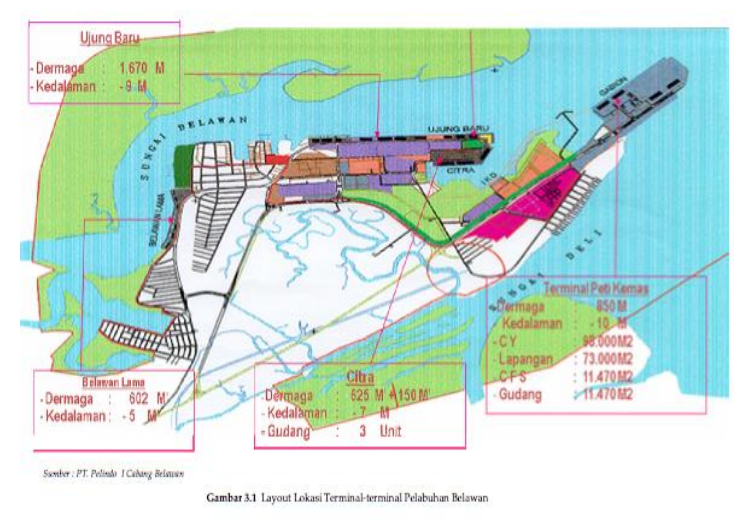

\section{Gambar 1 Layout lokasi terminal Pelabuhan Belawan}

Adapun fasilitas tersebut terdiri dari:

a. Belawan Lama (Dermaga 001-008)

b. Tambatan Antar Pulau Ujung Baru (Dermaga 101-104)

c. Ujung Baru (Dermaga 105-114)

d. Kolam Citra (Dermaga 201-203, Dermaga Semen Andalas dan IKD)

e. Jetty Pertamina

f. Terminal Gabion.

Kondisi alam Pelabuhan Belawan berada di muara di antara 2 sungai dan terbuka, sehingga secara alami mempunyai permasalahan terhadap aspek hidraulik dan lingkungan. Sedimentasi/siltasi merupakan permasalahan yang perlu mendapatkan perhatian di samping terbatasnya lebar alur pelayaran yang ada.Pelabuhan Belawan terletak pada ruang ekosistem perairan Selat Malaka, ekosistem estuaria Sungai Belawan, Sungai Deli, dan ekosistem vegetasi pantai di sekitarnya. Keberadaan Pelabuhan Belawan berada dalam pengaruh DAS Sungai Belawan dan Sungai Deli yang melintasi beberapa daerah/ wilayah administratif, yaitu Kotamadya Medan, Kabupaten Karo, Kabupaten Deli Serdang, dan Kabupaten Langka

\subsection{Lokasi Pengambilan Sampel}

Dalam upaya untuk mendapatkan sampel yang diperlukan, Pneliti berusaha bekerjasama dengan PELINDO I dan PT PENGERUKAN INDONESIA, namun dikarenakan beberapa hal, bantuan dari dua Persero diatas tidak berhasil didapatkan. Peneliti berusaha 


\section{Reutulisasi Sedimen Hasil Pekerjaan Pengerukan Sebagai Material Baru Dalam Pekerjaan Pembangunan Jalan}

mendapatkan sampel yang diperlukan melalui usaha yang dilakukan sendiri.

Beberapa lokasi tempat pengambilan sampel yang direncanakan adalah :

a. Lokasi Alur Pelayaran

b. Lokasi Alur Kolam Citra Pelabuhan

Lokasi Pengambilan sampel di kedua tempat ini dapat dilihat dari denah yang dilampirkan dihalaman berikutnya.Beberapa lokasi yang direncanakan untuk tempat pengambilan sampel yang akan digunakan dalam penelitian ini.

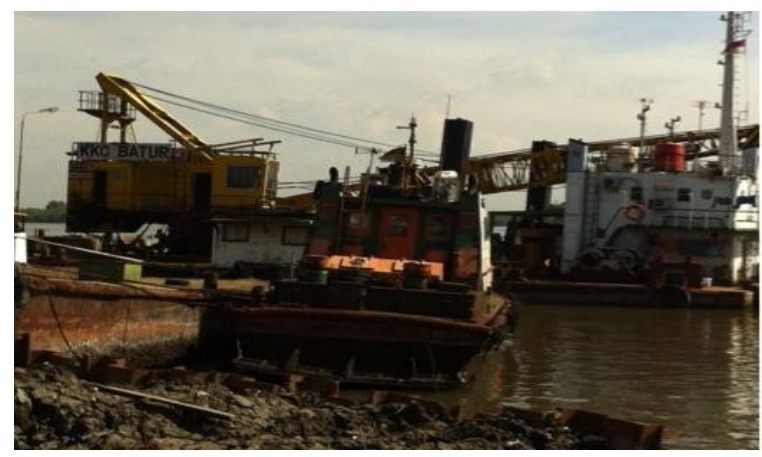

Gambar 2: Lokasi dermaga perbaikan kapal PELINDO I

Pemilihan lokasi ini berdasarkan kondisi lokasi yang diharapkan dapat mewakiili kondisi yang diperlukan dalam mendapatkan sampel sesuai dengan perkiraan. Namun sangat disayangkan untuk mendapatkan izin dalam mengambil sampel ini tidak mudah, untuk itu peneliti berusaha untuk mendapatkan sampel dari lokasi-lokasi lain disekitar PELABUHAN BELAWAN yang diperkirakan dapat mewakili kondisi seperti yang dimiliki lokasi Alur Pelayaran dan Lokasi Alur Kolam Citra. Salah satu Lokasi tempat Pengambilan sampel yang direalisasikan adalah : Lokasi tempat penyimpanan atau perbaikan kapal yang berada sekitar 6-8 kilometer dari Terminal Penumpang. Lokasi dermaga perbaikan kapal ini dapat dilihat pada foto 2 .

\section{Pembahasan dan Hasil Penelitian}

\subsection{Formulasi sampel}

Formulasi yang direalisasikan berdasarkan hasil dari mekanik dan kimia dari percobaan sebelumnya, selain itu juga berdasarkan tinjauan dari segi ekonomis. Beberapa formulasi sampel yang direalisasikan bertujuan untuk mengidentifikasi pengaruh dari berbagai agen pengikat (semen atau kapur) dalam performa mekanik maupun performa kimia dari sampel. Sampel dengan persentase semen 10\% direalisasikan bukan untuk nantinya diaplikasikan ke pekerjaan lapangan, melainkan sebagai alat untuk mengidentifikasi pengaruh dari agen pengikat (semen), karena berdasarkan segi ekonomis persentase semen sebesar $10 \%$ tidak disarankan. Peningkatan persentase semen dari 3\%,5\%,7\% dan 10\% direalisasikan untuk mengklarifikasi kehadiran semen dalam sedimen.

Tabel 1 Formulasi campuran sampel yang direalisasikan

\begin{tabular}{|c|c|c|}
\hline No & Semen $(\%)$ & Kapur \\
\hline CEM3-LIM3 (L1) & 3 & 3 \\
\hline CEM5-LIM3 (L1) & 5 & 3 \\
\hline CEM7-LIM3(L1) & 7 & 3 \\
\hline CEM10-LIM3(L1) & 10 & 3 \\
\hline CEM3-LIM3 (L2) & 3 & 3 \\
\hline CEM5-LIM3 (L2) & 5 & 3 \\
\hline CEM7-LIM3(L2) & 7 & 3 \\
\hline CEM10-LIM3(L2) & 10 & 3 \\
\hline CEM3-LIM5 (L1) & 3 & 5 \\
\hline CEM5-LIM5 (L1) & 5 & 5 \\
\hline CEM7-LIM5 (L1) & 7 & 5 \\
\hline CEM10-LIM5 (L1) & 10 & 5
\end{tabular}

Peningkatan kapur juga dimaksud untuk mengidentifikasi efek dari penambahan 3\% kapur unutk sedimen L1, apakah pengaruh penambahan persentase kapur dalam sampel memberikan hasil yang signifikan atau tidak, apabila ditinjau dari segi perfroma mekanik (IPI, UCS, Tensile Test dll) begitu pula dari segi performa kimia (TCLP).

\subsection{Karakteristrik mekanik}

\subsubsection{Percobaan IPI dan Proctor}

Percobaan California Bearing Ration (CBR) direalisasikan untuk 12 formula baru pada tahun kedua (2014) ini. Tujuan utama dari percobaan CBR ini adalah untuk mengidentifikasi nilai Indeks Portance Immediate (IPI) dengan kondisi kadar air yang maksimal. Dalam pekerjaan pembangunan nilai IPI sangat diperlukan dalam menentukan dalam penggunaan material.Pada gambar 12 hasil percobaan California Bearing Ratio (CBR) 
menperlihatkan bahwa nilai IPI meningkat sesuai dengan bertambahnya persentase binder yang digunakan. Hasil percobaan memperlihatkan bahwa nilai IPI yang tertinggi adalah sampel dengan persentase binder $10 \%$ sement dan 5\% (CEM10-LIM5 L1) kapur untuk lokasi pengambilan sampe L1. Sampel dengan persentase semen yang samadengan lokasi yang berbeda (L2) (CEM10-LIM3 L2) hanya memperoleh21.8\%) Sampel dengan lokasi pengambilan L1, apabila kita perhatikan antara sampel CEM5-LIM3 (5\% semen dan 3\% kapur) dengan CEM5-LIM5 L1 (semen 5\% dan kapur $5 \%$ ) hasil percobaan memperlihatkan bahwa dengan penambahan persentase kapur sebanyak $2 \%$ tidak memperlihatkan peningkatan nilai IPI yang signifikan (13.8\% dan 13.9\%)(sesuai dengan persentase penambahan kapur .Hal ini disebabkan oleh kadar polusi yang terdapat pada sedimen sehingga menggangu proses reaksi kapur.

Tabel 2 : Hasil Percobaan Proctor dan CBR

\begin{tabular}{|l|l|l|l|}
\hline No & Nama & IPI $(\%)$ & $\begin{array}{l}\text { Kadar Air } \\
(\%)\end{array}$ \\
\hline 1 & $\begin{array}{l}\text { CEM3-LIM3 } \\
(\text { L1) }\end{array}$ & 12 & 19 \\
\hline 2 & $\begin{array}{l}\text { CEM5-LIM3 } \\
\text { (L1) }\end{array}$ & 13.8 & 20.7 \\
\hline 3 & $\begin{array}{l}\text { CEM7-LIM3 } \\
\text { (L1) }\end{array}$ & 14.5 & 21.04 \\
\hline 4 & $\begin{array}{l}\text { CEM10-LIM3 } \\
\text { (L1) }\end{array}$ & 15.2 & 22.1 \\
\hline 5 & $\begin{array}{l}\text { CEM3-LIM3 } \\
\text { (L2) }\end{array}$ & 11.5 & 18.38 \\
\hline 6 & $\begin{array}{l}\text { CEM5-LIM3 } \\
(\text { L2 })\end{array}$ & 12.9 & 19.94 \\
\hline 7 & $\begin{array}{l}\text { CEM7-LIM3 } \\
(\text { L2 })\end{array}$ & 13.83 & 20.98 \\
\hline 8 & $\begin{array}{l}\text { CEM10-LIM3 } \\
(\text { L2 })\end{array}$ & 14.7 & 21.8 \\
\hline 9 & $\begin{array}{l}\text { CEM3-LIM5 } \\
\text { (L1) }\end{array}$ & 13.9 & 20.3 \\
\hline 10 & $\begin{array}{l}\text { CEM5-LIM5 } \\
\text { (L1) }\end{array}$ & 14.7 & 21.8 \\
\hline 11 & $\begin{array}{l}\text { CEM7-LIM5 } \\
\text { (L1) }\end{array}$ & 15.04 & 22.9 \\
\hline 12 & CEM10;LIM5 & 15.89 & 24.02 \\
\hline
\end{tabular}

\begin{tabular}{|l|l|l|l|}
\hline & (L1) & & \\
\hline
\end{tabular}

Berdasarkan penelitian yang telah dilakukan sebelumnya menemukan bahwa penambahan binder kapur membantu dalam menaikkan nilai $\mathrm{pH}$ sampel menjadi sangat tinggi $(\mathrm{pH}=12)$ dan hal ini memberikan dampak positif untuk kinerja binder lainya.Kehadiran kapur akan terus memberikan ketahanan ekstra selama kondisi pH diatas 12, tingginya nilai $\mathrm{pH}$ ini mengakibatkan disolusi dari ion Kalsium, dimana sedimen mengeluarkan alumunium dan silica yang nantinya akan bereaksi terhadap ion Kalsium sehingga membentuk C-S-H dan C-A-H. Teori ini dapat dikonfirmasi dengan hasil yang didaptkan dalam percobaan ini, dimana penambahan persentase kapur tidak memperlihatkan perbedaan peningkatan nilai CBR yang signifikan, Hal ini disebabkan oleh kehadiran elemen polusi yang mengganggu proses kimia dalam memperoleh kekuatan dalam waktu yang singkatHasil percobaan juga memperlihatkan bahwa peningkatan semen dan kapur meningkatkan kadar air dari sampel. Hal ini tentunya disebabkan oleh meningkatnya persentase dari agen pengikat (semen dan kapur) dalam sampe membuat sampel tersebut membutuhkan jumlah air yang lebih banyak untuk mencapai kondisi ideal. Teori ini terbukti pada peningkatan semen sebesar 2\% antara CEM3-LIM3 L1, CEM5LIM3\% L1, CEM7-LIM5 L1, CEM10-LIM5 L1 dimana kadar air tidak memperlihatkan peningkatan yg signifikan dalam peningkata kadar air begitu pula nilai IPI.

\subsubsection{Percobaan daya tekan (Unconfined Compressive Strength)}

\section{a. Dampak semen terhadap performa mekanik}

Tujuan utama dalam merealisasikan percobaan UCS iniadalah untuk mengetahui peningkatan performa mekanik dari sampel, dan juga untuk mengidentifikasi efek yang diberikan oleh binder yang digunakan dalam performa mekanik.Hasil dari percobaan daya tekan (UCS) ini diperlihatkan pada gambar 3.Hasil percobaan ini khusu direalisasikan untuk mengidentifikasi dampak persentase semen yang ditambahkan kedalam campuran. 


\section{Reutulisasi Sedimen Hasil Pekerjaan Pengerukan Sebagai Material Baru Dalam Pekerjaan Pembangunan Jalan}

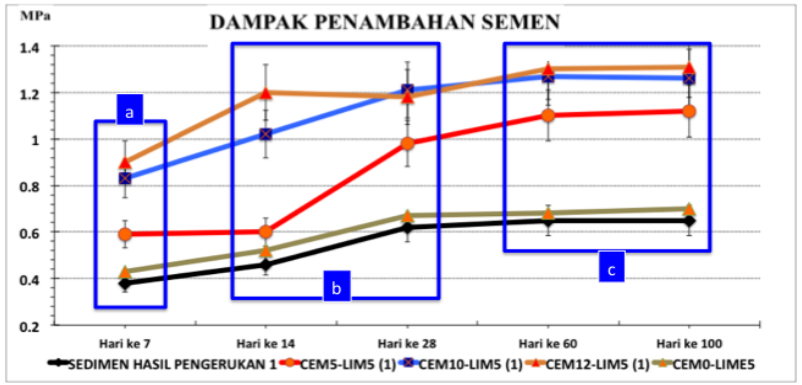

Gambar 3 Hasil Percobaan UCS untuk penambahan persentase semen

Pada hasil percobaan UCS ini sampel yang digunakan hanya sampel yang diambil pada lokasi depot perbaikan kapal (L1), untuk mempermudah pengidentifikasian dampak penambahan semen dalam campuran, penggolongan peningkatan nilai daya tekan dikategorikan dalam 3 periode, periode pertama.

Hasil percobaan UCS ini direalisasikan untuk mengidentifikasi dampak persentase semen yang ditambahkan kedalam campuran. Pada hasil percobaan UCS ini sampel yang digunakan hanya sampel yang diambil pada lokasi depot perbaikan kapal (L1), seperti yang dapat diperhatikan untuk mempermudah pengidentifikasian dampak penambahan semen dalam campuran, penggolongan peningkatan nilai daya tekan dikategorikan dalam 4 periode, periode pertama

a. Dimana periode memperlihatkan performa sampel pada curing age awal (7 hari), periode kedua

b. Untuk curing age menengah (14 hari) periode ketiga

c. Untukcuring age menengah (28 hari) dan periode keempat

d. Untuk mengidentifikasi performa mekanik dengan curingperiode jangka panjang (60-100 hari).

Persentase kapur tetap dipertahankan di $5 \%$, jumlah persentase ini merupakan jumlah persentase kapur yang biasa digunakan dalam pekerjaan pembangunan jalan Sampel.Periode (a) memperlihatkan nilai UCS dimana sampel (Sedimen hasil pengerukan) tanpa ada campuran binder memiliki nilai UCS yang terendah $(0.38 \mathrm{MPa})$, sementara sampel dengan nilai UCS tertinggi diperoleh oleh sampel dengan persentase semen yang tertinggi yaitu $12 \%$.Semen sebagai binder hydraulic telah dibuktikan dapat meningkatkan performa mekanik dalam waktu yang singkat (Yin et Lai 1998) [12]. Reaksi kimia dari semen memakan waktu sangat singkat, sehingga peningkatan performa sampel akan terlihat di jangka pendek /curing age awal (7-28 hari). Seperti telah diketahui bahwa reaksi semen secara singkat dijabarkan sebagai berikut, dimana $\mathrm{C}_{3} \mathrm{~S}$ berhidratasi lalu memproduksi C-S-H yang berbentuk gel dan portlandite.

Sebagian besar bagian dari hidrasi diproduksi dalam jangka waktu 28 hari akan tetapi reaksi hidratasi dapat selesai sepenuhnya dalam jangka waktu 1 tahun. $\mathrm{C}_{2} \mathrm{~S}$ berhidratasi dan membentuk gel C-S-H dan Portlandite akan tetapi $\mathrm{C}_{2} \mathrm{~S}$ menghasilkan jumlah yang jauh lebih sedikit dibanding $\mathrm{C}_{3} \mathrm{~S}$. C-S-H dan Portlandite berperan sangat penting dalam memberikan kekuatan/performa dari sampel. Periode curing age menengah 14-28 hari (b) memperlihatkan hasil yang tidak jauh berbeda dari periode sebelumnya (7 hari) dimana sampel sedimen hasil pengerukan tanpa ada campuran binder memiliki nilai UCS yang terendah $(0,44 \mathrm{MPa})$, sementara sampel dengan nilai UCS tertinggi diperoleh oleh sampel dengan persentase semen yang tertinggi yaitu 12\% (CEM12-LIM5) dengan nilai UCS 1.2 MPa. Hal ini memperlihatkan bahwa semen berperan penting dalam peningkatan performa.Periode curing age jangka panjang 60-100 hari (c) mulai memperlihatkan hasil yang sedikit berbeda dibanding Periode curing age awal ataumenengah (a atau $\mathbf{b})$. Perbedaan antara sampel dengan persentase semen 10\% (CEM10LIM5) dan 12\% (CEM12-LIM5) hampir tidak terlihat. Dapat kita perhatikan juga bahwa sampel dengan semen dalam campuran memperlihatkan peningkatan performa mekanik dari periode curing age awal hingga periode curing age jangka panjang, akan tetapi dapat disimak pula bahwa peningkatan performa mekanik dari sampel berkurang drastic setelah sampel mencapai hari ke 60, hal ini disebabkan oleh majoritas reaksi semen telah selesai dalam memproduksi C-S-H yang berperan penting dalam peningkatan performa mekanik. Sampel dengan sedimen origin (tanpa penambahan binder) tidak memperlihatkan peningkatan performa mekanik sama sekali setelah hari ke 60, peningkatan performa mekanik yang tidak begitu tinggi, dari $0,4 \mathrm{MPa}$ (pada hari ke 7) hingga 0,62 $\mathrm{MPa}$ (pada hari ke 100) peningkatan nilai UCS sebesar $0,2 \mathrm{Mpa}$ ini disebabkan oleh pengeringan sampel dimana air dalam sedimen menguap sesuai dengan 
waktu dan matriks sampel mulai mengeras sehingga memproduksi peningkatan performa mekanik. Berdasarkan hasil ini pula dapat disimpulkan, dari sisi performa mekanik, sedimen origin hasil pengerukan tidak dapat digunakan langsung tanpa adanya campuran bahan lain, hal ini dikarenakan oleh syarat yang harus dipenuhi minimal sebesar $1 \mathrm{MPa}$ (untuk periode curing age 28 hari) tidak terpenuhi.

\section{b. Dampak kapur terhadap performa mekanik}

Penambahan kapur dalam campuran direalisasikan dengan pertimbangan bahwa penggunaan kapur telah terbukti selama ini dapat meningkatkan performa dari sampel yang digunakan.Hasil Percobaan Unconfined Compressive Strength diperlihatkan di gambar 4 dimana 6 sampel dengan formulasi binder yang berbeda. Persentase jumlah kapur didalam campuran dimulai dari $0 \%$ (CEM5LIM0), 5\% (CEM5-LIM5) dan 10\% (CEM5-LIM 10). Berdasarkan pengalaman peneliti dalam pekerjaan stabilisasi tanah, persentase kapur pada campuran diatas $10 \%$ tidak direkomendasikan, dikhawatirkan dengan persentase kapur yang terlalu tinggi dapat memprovokasi pembengkakan akibat reaksi yang ditimbulkan oleh kapur. Untuk mempermudah analisa, hasil percobaan daya tekan ini (UCS) ini dikategorikan dalam 3 periode (telah diterangkan di sub bab sebelumnya.

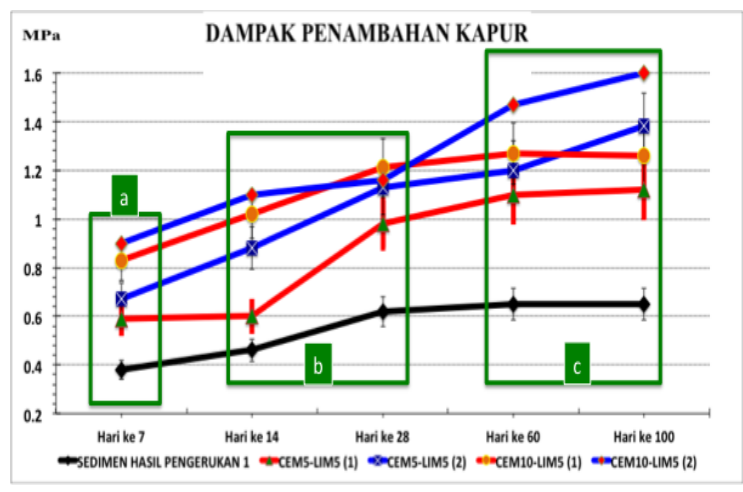

Gambar 4 Hasil Percobaan UCS untuk dampak penambahan persentase kapur

Pada Periode curing age awal (a) nilai daya tekan (UCS) antara binder dengan persentase kapur $0 \%, 5 \%$ dan $10 \%$ tidak menunjukkan perbedaan yang signifikan. Sampel dengan persentase semen 5\% dan kapur 5\% dan dari lokasi L2 memperlihatkan nilai daya tekan yang tertinggi $(0,68 \mathrm{MPa})$ disbanding sampel dari lokasi L1. Hal ini disebabkan oleh reaksi kapur dalam memberi peningkatan performa mekanik tergolong lambat. Reaksi kapur umumnya memerlukan waktu sekitar 60 hari (tergantung kadar reakstif dari kapur itu sendiri) untuk dapat memberikan hasil yang maximal. Reaksi kapur memprovokasi peningkatan $\mathrm{pH}$ sampel sehingga dengan waktu berjalan ion Kalsium dari matriks sedimen akan membentuk C-S-H dan $\mathrm{C}-\mathrm{A}-\mathrm{H}$, yang mempunyai peranan utama dalam peningkatan performa dari sampel. Hal ini menjelaskan mengapa tidak terlihat perbedaan yang signifikan pada nilai daya tekan dari beberapa sampel (dengan formulasi yang berbeda). Pada periode curing age awal (7 hari) reaksi kapur dalam menaikkan $\mathrm{pH}$ diperkirakan hanya membantu mengendapkan air yang terdapat dalam sampel sehingga sampel lebih cepat mencapai tingkat solid, sehingga memperoleh performa mekanik. Periode curing age menengah (14-28 hari) perbedaan nilai daya tekan semakin terlihat jelas, dimana sampel dengan persentase kapur sebesar $10 \%$ memperlihatkan peningkatan nilai UCS. Sampel dengan 5\% kapur dan 5\% semen (CEM5-LIM5) dengan sedimen berasal dari L1 tetap memperlihatkan nilai daya tekan terbesar, pada periode curing age menengah ini terutama pada hari ke 28 , hanya sampel dengan sedimen L2 ini yang melewati kekuatan daya tekas sebesar $1 \mathrm{MPa}$. Nilai daya tekan $1 \mathrm{MPa}$ merupakan batas yang diperlukan dalam penggunaan pembangunan jalan.Sampel sedimen dari lokasi L1 memperlihatkan kekuatan daya tekan yang hampir mendekati 1 $\mathrm{MPa}$. Perbandingan antara sampel dengan sedimen L1 dan L2 memperlihatkan perbedaan yang penting, walaupun dengan formulasi yang sama (5\% semen dan 5\% kapur). Hal ini disebabkan oleh tingginya tingkat polusi dari sampel dengan sedimen yang berasal dari lokasi alur kolam citra (L1). Berdasarkan pengalam peneliti, elemen polusi apabila mencapai jumlah tinggi akan mengganggu reaksi dari binder yang digunakan, baik itu reaksi semen ataupun reaksi kapur. Tingginya elemen penyebab polusi ini dapat memperlambat proses pembentukan clincker (pada hidratasi semen) dan menghambat kenaikan $\mathrm{pH}$ (pada reaksi kapur) sehingga hal ini menyebabkan terhambatnya sampel dalam 


\section{Reutulisasi Sedimen Hasil Pekerjaan Pengerukan Sebagai Material Baru Dalam Pekerjaan Pembangunan Jalan}

mencapai performa mekanik yang maksimal. Hal ini dapat disimak dari tabel 1 dimana terlihat dari hasil Toxcity Characteristic Leaching procedure (TCLP) ditemukan bahwa sedimen berasal dari lokasi L1 jauh lebih berpolusi dari sedimen L2. Terutama Cadmium (Cd) dan Cooper (Cu).Faktor ini yang menyebabkan terhambatnya reaksi binder (semen dan kapur) sehingga sampel dengan sedimen dari lokasi L1 (CEM5-LIM5-L1) menghasilkan nilai daya tekan (UCS) lebih kecil dari sedimen dari lokasi L2 (CEM5-LIM5-L2). Period curing age jangka panjang (60-100 hari) hasil percobaan memiliki pola yang sama dengan Period curing age menengah, sampel dari Lokasi L2 (CEM5-LIM5-L2) masih menunjukkan hasil percobaan daya tekan yang terbaik, diikuti oleh (CEM5-LIM5-L1) dan (CEM5-LIM10-L1). Sampel dari lokasi L2 (CEM5-LIM5-L2) menunjukkan peningkatan yang tinggi dari kekuatan terhadap daya tekan.Hal ini disebabkan oleh reaksi dari hidratasi dari kapur dalam menaikkan $\mathrm{pH}$ dan hydratasi dari ion Kalsium dan ion Alumunium lalu membentuk gel C-S-H dan C-A-H. Sampel dengan formulasi yang sama dengan sedimen dari L1 (CEM5-LIM5-L1) tidak memperlihatkan peningkatan daya tahan terhadap daya tekan sebaik sampel dari L2. Peningkatan nilai daya tekan pada hari ke 60 dan 90 disebabkan oleh reaksi hidratasi kapur, hal ini dapat dibuktikan dengan memperhatikan gambar 4 dimana evolusi daya tekan sampel tanpa ada campuran kapur $(0 \%)$ didalamnya (CEM5-LIM0), sampel ini hampir tidak memperlihatkan peningkatan nilai daya tekan setelah hari ke 28. Absennnya kehadiran kapur dalam sedimen ini yang membuat tidak ada peningkatan daya tekan (UCS) karena setelah 28 hari, menurut teori, reaksi semen (hidratasi clinker) hampir selesai setelah 28 hari. Hal ini dapat diverifikasi apabila kita perhatikan bahwa evolusi nilai daya tekan sampel ini (CEM5-LIM0) pada periode curing age dari 28 hari sampai 100 hari hampir sama dengan sampel origin (tanpa binder).

\section{c. Percobaan gaya Tarik (Tensile Strength)}

Salah satu percobaan yang sagat menentukan dalam pengidentifikasi performa mekani dari sampel adalah percobaan Tensile Strength (TS), dimana percobaan ini direalisasikan untuk mengidentifikasi performa mekanik melalui modul elastisitas dan kekuatan gaya tarik. Nilai maksimal dari gaya yang diterapkan digunakan untuk menghitung kekuatan gaya tarik dengan menggunakan rumus dibawah ini:

$$
R t=0,8 R t b=0,8 * 2 * 10 \quad 2 * \frac{F r}{h}
$$

Rt: Kekuatan gaya tarik diestimasi dari Rtb (MPa)

Rtb : Kekuatan gaya tekan diametral (MPa)

Fr : Gaya yang diaplikasi ke sampel pada saat kondisi runtuh $(\mathrm{N})$

$\mathrm{h}$ : Tinggi sampel $(\mathrm{cm})$

$\Phi$ : diameter sampel (cm)

Menurut peraturan kita dapat menghitung Kekuatan gaya tarik (Rt) dan modul elastisitas (E) dengan sampel yang berumur (curing periode) 360 hari. Perhitungan tersebut menggunakan rumus dibawah ini (persamaan 10 dan 11)

$$
\begin{aligned}
& \frac{\text { Rt } 28 \text { hari }}{\text { Rt } 360 \text { hari }}=0,60 ; \\
& \frac{\text { E28hari }}{\text { E360hari }}=0,65 \\
& \frac{\text { Rt } 60 \text { hari }}{\text { Rt } 360 \text { hari }}=0,70 ; \\
& \frac{\text { E60hari }}{\text { E360hari }}=0,75
\end{aligned}
$$

Seperti yang telah dilakukan sebelumnya pada tahun pertama dimana sampel yang digunakan sampai pada saat percobaan akan dilakukan berumur 100 hari. Berdasarkan perhitungan yang tleah dilakukan pada tahun pertama (2014) dimana persamaan untuk menghitung kekuatan gaya tarik dan Modul Elastisitas (1) dan (2) dimodifikasi dengan memperhitungkan kecepatan dari penekanan gaya, modifikasi ini dihitung sebesar 10 kali lipat dari ekcepatan yang biasa digunakan dalam percobaan, sehingga berdasarkan perhitungan tersebut maka peneliti menghasilkan persamaan yang digunakan untuk menghitung Kekuatan Gaya Tarik dan Modul Elastisitas dengan umur sampel 90 hari. Alat yang digunakan adalah 
alat tekan sama yang digunakan dalam percobaan CBR, Unconfined Compressive Strength dengan menggunakan alat bantu yang berguna sebagai dudukan sampel.

Tabel 3. Hasil perhitungan Kekuatan gaya tarik (Rt)

\begin{tabular}{|l|c|}
\hline \multicolumn{1}{|c|}{ No } & Rt (MPa) \\
\hline CEM3-LIM3 (L1) & 0.43 \\
\hline CEM5-LIM3 (L1) & 0.58 \\
\hline CEM7-LIM3(L1) & 0.76 \\
\hline CEM10-LIM3(L1) & 1.1 \\
\hline CEM3-LIM3 (L2) & 0.32 \\
\hline CEM5-LIM3 (L2) & 0.56 \\
\hline CEM7-LIM3(L2) & 0.72 \\
\hline CEM10-LIM3(L2) & 10 \\
\hline CEM3-LIM5 (L1) & 0.34 \\
\hline CEM5-LIM5 (L1) & 0.51 \\
\hline CEM7-LIM5 (L1) & 0.70 \\
\hline CEM10-LIM5 (L1) & 1.2 \\
\hline
\end{tabular}

Hasil percobaan Tensile strength untuk menghitung kekuatan geser untuk sampel berumur 90 tahun dipaparkan di table 3 . Percobaan ini dilakukan terhadap empat formulasi yang dipilih untukmengidentifikasi efek dari binder. Setiap formula diwakili oleh dua sampel, berdasarkan hasil percobaan dapat kita simpulkan bahwa sampel dengan formulasi 5\% semen dan $10 \%$ kapur dengan sedimen berasal dari lokasi L1 memperlihatkan kekuatan gaya tarik yang terbaik diantara sampel dengan formulasi lainnya. Nilai yang didapatkan $(0.15 \mathrm{MPa}-0.3)$ merupakan nilai yang cukup memenuhi persyaratan apabila sedimen dengan fornulasi-formulasi tersebut untuk digunakan sebagai bahan dalam pembangunan jalan raya. Sampel dengan persentase kapur terbesar (10\%) memperlihatkan kekuatan gaya tarik terbesar. Hal tersebut membantu peneliti dalam menarik kesimpulan bahwa kehadiran kapur sangat membantu performa mekanik terutama pada saat curing age100 hari dimana dapat dipastikan bahwa pada period tersebut reaksi kapur telah mencapai kondisi maksimal. Sampel dengan formulasi tanpa kapur memperlihatkan nilai kekuatan gaya tarik terendah, performa mekanik dari sampel ini hanya didapat dari reaksi semen yang diperkirakan telah berhenti setelah curing period60 hari, dengan tidak hadirnya kapur dalam campuran maka, reaksi pozzolanic yang memberikan kekuatan ekstra pada periode jangka panjang akibat dari reaksi kapur tidak muncul.

Tabel 4 Hasil perhitungan Modul Elastisitas (E)

\begin{tabular}{|l|c|}
\hline \multicolumn{1}{|c|}{ No } & Semen $(\%)$ \\
\hline CEM3-LIM3 (L1) & 1.7 \\
\hline CEM5-LIM3 (L1) & 1.95 \\
\hline CEM7-LIM3(L1) & 1.53 \\
\hline CEM10-LIM3(L1) & 2.93 \\
\hline CEM3-LIM3 (L2) & 1.52 \\
\hline CEM5-LIM3 (L2) & 2.1 \\
\hline CEM7-LIM3(L2) & 1.74 \\
\hline CEM10-LIM3(L2) & 3.1 \\
\hline CEM3-LIM5 (L1) & 1.83 \\
\hline CEM5-LIM5 (L1) & 2.03 \\
\hline CEM7-LIM5 (L1) & 1.84 \\
\hline CEM10-LIM5 (L1) & 3.42 \\
\hline
\end{tabular}

Hasil dari percobaan Tensile dalam menghitung Modul Elastisitas diperlihatkan di table 4. Nilai dan pola kekuatan gaya tarik yang didapat pada perhitungan Modul Elastis ini menunjukkan pola yang sama pada perhitungan kekuatan gaya tarik, dimana sampel dengan persentase kapur 10\% (CEM5LIM10) L1 dengan sedimen berasal dari lokasi L1 menunjukkan nilai modul Elastisitas yang lebih tinggi dibanding sampel lainnya. Sampel dengan semen 5\% dan kapur 5\% (CEM5-LIM5) L1 memperlihatkan nilai mendekati sampel (CEM5-LIM10) L1. Hal yang dapat diperhatikan pada perhitungan ini adalah perbedaan yang tidak mencolok pada nilai Modul Elastisitas antara sampel dengan 10\% kapur (CEM5-LIM10) L2 dengan sampel tanpa kapur (CEM5-LIM0) L1. Hal ini disebabkan oleh lebih tingginya kadar polusi yang ada pada lokasi L2 dibanding sedimen di lokasi L1. Kadar polusi pada sedimen L2 menghambat reaksi kapur yang ada pada campuran, sehingga persentase dari kapur sebesar 10\% tidak berpengaruh penting pada peningkatan performa mekanik

\section{Kesimpulan}

Percobaan ini merupakan percobaan lanjutan untuk meneliti karakteristik mekanik dari sedimen hasil pekerjaan pengerukan Pelabuhan Belawan agar aman aman dan sesuai memenuhi syarat pekerjaan jalan. Peneliti 


\section{Reutulisasi Sedimen Hasil Pekerjaan Pengerukan Sebagai Material Baru Dalam Pekerjaan Pembangunan Jalan}

merealisasikan 12 formula baru dimana campuran terdiri dari sedimen hasil pekerjaan pengerukan Pelabuhan Belawan, agen pengikat (semen dan kapur) beserta air. Hasil dari percobaan yang diperoleh beberapa hasil yang memuaskan untuk memenuhi syarat pekerjaan jalan.

Pada percobaan Proctor/ CBR memberikan hasil bahwa sedimen setelah proses stabilisasi dengan agen pengikat (semen dan kapur dapat dipergunakan dalam pekerjaan pembangunan jalan, percobaan ini juga mengidentifikasi bahwa peningkatan nilai IPI berbanding lurus dengan peningkatan persentase agen pengikat dalam sampe, begitu pula peningkatan persentase agen pengikat berdampak dalam bertambahnya nilai kadar air ideal dari sampel.

Pada Percobaan daya tekan/ Unconfined Compressice Strength (UCS) memperlhatakn hasil yang sangat memuaskan, dimana seluruh sampel setelah 28 hari menghasilkan nilai daya tekan diatas $1 \mathrm{MPa}$, yang merupakan syarat nilai minimum daya tekan dalam pembangunan jalan raya. Beberapa sampel juga memperlihatkan peningkatan nilai daya tekan yang sangat menjanjikan. Dari percobaan ini pula dapat diidentifikasi bahwa kehadiran semen memberikan peningkatan dalam memperoleh nilai daya tekan dalam waktu yang singkat (7-14 hari), sementara kapur memberikan peningkatan nilai daya tekan pada waktu yang lebih panjang (60-180 hari) yang merupakan hasil dari kinerja pozzolan.Percobaan Tensile memperlihatkan hasil yang sesuai dengan diharapkan, dimana seluruh sampel dengan formula yang bervariasi memperoleh hasil yang memuaskan dalam persyaratan pembangunan jalan.

\section{Daftar Pustaka}

SILITONGA E.(2010), Valorisation des sédiments marins contaminés par solidification/ stabilisation à base de liants hydrauliques et de fumée de silice. Thesis doctorat Université de Caen, France, 2010, 160p.

SILITONGA.,LEVACHER. D., MEZAZIGH S. (2009), Effects of theuse of fly ash as a binder on the mechanical behavior of treated dredged sediments, Environmental Technology (2009) vol 30.
SILITONGA.,LEVACHER. D., MEZAZIGH S. (2010)Utilization of fly ash for stabilization of marine dredged sediments, 2010, Revue Européenne de Génie Civil et Environnement, Volume 14 Issue 2, pages 253-265 